\title{
Detection of picomole amounts of biological substrates by parahydrogen enhanced NMR methods in conjunction with a suitable receptor complex
}

\author{
Nicholas J. Wood, James A. Brannigan, Simon B. Duckett, ${ }^{\star}$ Sarah L. Heath ${ }^{a}$ and Jane Wagstaff
}

\author{
Department of Chemistry, University of York, Heslington, YO10 5DD, York, UK. \\ ${ }^{a}$ Department of Chemistry, University of Manchester, Oxford Road, Manchester M13 9PL, UK \\ RECEIVED DATE (automatically inserted by publisher); Fax: +44 1904 432516; E-mail : sbd3@york.ac.uk
}

\begin{abstract}
An NMR tube was made up that contained $\operatorname{IrCl}(\mathrm{CO})\left(\mathrm{PPh}_{3}\right)_{2}$ in benzene- $\mathrm{d}_{6}$ and charged with $42 \mu \mathrm{mol}$ of benzimidazole and 3 atm $p-\mathrm{H}_{2}$; upon raising the temperature of the sample to $345 \mathrm{~K}$, two new hydride signals were observed in the ${ }^{1} \mathrm{H}$ NMR spectrum, attributable to 2 , the benzimidazole analogue of $\mathbf{1}$. Surprisingly, subsequent cooling of the sample to $325 \mathrm{~K}$ resulted in an increase in magnitude for these signals. This observation implies that the enhanced product $\mathbf{2}$ is not formed from the direct reaction of benzimidazole with $\operatorname{IrCl}(\mathrm{CO})\left(\mathrm{PPh}_{3}\right)_{2}$, and subsequent addition of $p-\mathrm{H}_{2}$, but is formed instead from the reaction of benzimidazole with the dihydride complex $\operatorname{IrCl}(\mathrm{CO})(\mathrm{H})_{2}\left(\mathrm{PPh}_{3}\right)_{2}$, which undergoes $\mathrm{CO}$ loss to form $\operatorname{IrCl}(\mathrm{H})_{2}\left(\mathrm{PPh}_{3}\right)_{2}$. In this way, greater signal magnitudes could be attained by allowing the reaction of $\operatorname{IrCl}(\mathrm{CO})\left(\mathrm{PPh}_{3}\right)_{2}$ with hydrogen to go to completion, then adding the $\mathrm{N}$-donor, degassing the sample and pressurising the sample with $p-\mathrm{H}_{2}$. Simple tests qualitatively confirmed this assertion, and so further experiments were carried out using this method. The benzimidazole complex 2 was characterised at $325 \mathrm{~K}$ and the ${ }^{15} \mathrm{~N}$ chemical shift of the coordinated nitrogen atom located on a non-enriched sample (Table 1).
\end{abstract}

The ligating potential of purine is complicated by its tautomeric nature. Scheme 2 in the paper shows the two principal tautomers, $\mathrm{N}^{9}-\mathrm{H}$ purine and $\mathrm{N}^{7}-\mathrm{H}$ purine, which differ according to the position of the $\mathrm{NH}$ proton in the imidazole moiety of the molecule. In principle, therefore, six different coordination sites are available; however, the products of $\mathrm{N}^{1}$-coordination of the $\mathrm{N}^{9}-\mathrm{H}$ tautomer and $\mathrm{N}^{1}$ coordination of the $\mathrm{N}^{7}-\mathrm{H}$ tautomer are expected to be indistinguishable by this method, as are the products of $\mathrm{N}^{3}$ coordination of the $\mathrm{N}^{9}-\mathrm{H}$ and $\mathrm{N}^{7}-\mathrm{H}$ tautomers, therefore four distinguishable products may be observed. Theoretical studies suggest that the $\mathrm{N}^{9}-\mathrm{H}$ tautomer is more stable than the $\mathrm{N}^{7}-\mathrm{H}$ tautomer. ${ }^{1}$

The products 3a-d can be partially assigned by comparison of their ${ }^{1} \mathrm{H}$ NMR data with that of $\mathbf{1}$ and 2 . Inspection of the chemical shifts of the trans-to-nitrogen hydride signals shows that this parameter is diagnostic of the type of heterocyclic ring in which the ligating nitrogen is situated, such that hydride signals in the approximate region $\delta-19.2$ to -19.8 arise from coordination via a five-membered ring, whereas $\delta-21.0$ to -21.5 arise from coordination via a six membered ring. In the case of $\mathbf{3 a - d}$, it is therefore evident that $\mathbf{3 a}$ and $\mathbf{3 b}$ are species which contain the purine ligand bound via the sixmembered pyrimidine moiety, while $\mathbf{3 c}$ and $\mathbf{3 d}$ contain purine bound via the five-membered imidazole moiety.

The binding mode of the purine ligand was further determined by 2D nOe spectroscopy where connections for the resonance of the hydride trans to chloride (and therefore cis to the purine ligand) provided the crucial information. Comparison of the ${ }^{1} \mathrm{H}$ chemical shifts of the coordinated purine with those of the free purine should provide enough information to assign the structures of 3a-d; unfortunately, the solubility of purine in $d_{8}$-toluene is so low that $d_{6}$-DMSO based information has been used in its place. ${ }^{2}$ For $\mathbf{3 a}$, in addition to a signal arising from the proximity of the orthophenyl protons of the triphenylphosphine ligands, the $\delta-22.66$ hydride signal shows two nOe interactions to purine ligand protons which resonate at $\delta 8.98$ and $\delta$ 8.65; 3a must consequently correspond to a product where the purine is bound via $\mathrm{N}^{1}$ because this is the only binding site which has two adjacent protons $\left(\mathrm{H}^{6}\right.$ and $\left.\mathrm{H}^{2}\right)$. In free purine, these protons usually resonate (in $\mathrm{d}_{6}$-DMSO) at $\delta \quad 9.21$ and $\delta 8.99$ respectively; it appears that, upon coordination, the resonances of the protons are shifted upfield by approximately $0.3 \mathrm{ppm}$ relative to the free purine. The $\mathrm{N}^{1}$ site of purine is the most basic and least sterically hindered nitrogen donor site in the molecule, which is consistent with the formation of the $\mathrm{N}^{1}$ ligated product $3 \mathbf{a}$ as the most abundant product. ${ }^{3,10}$ The parahydrogen enhancement attained in the case of 3a proved to be great enough to allow the rapid location of a ${ }^{15} \mathrm{~N}$ signal at $\delta-177$ for the coordinated $\mathrm{N}^{1}$ nitrogen with the label at natural abundances. The ${ }^{15} \mathrm{~N}$ chemical shift was acquired via its coupling to the $\delta-21.37$ hydride signal of $3 a$, using a ${ }^{1} \mathrm{H}^{15} \mathrm{~N}$ HMQC experiment optimised for a ${ }^{2} J_{\mathrm{NH}}$ value of $12 \mathrm{~Hz}$ For $\mathbf{3 b}$, although the signals are of lower intensity than those of $\mathbf{3 a}$, the $\delta-21.80$ hydride signal shows one nOe interaction arising from protons on the purine ligand, at $\delta 8.64$. This supports the assignment of $\mathbf{3 b}$ as a product arising from $\mathrm{N}^{3}$-coordination of purine, as only the $\mathrm{H}^{2}$ proton is adjacent to the binding site; again, coordination shifts the $\mathrm{H}^{2}$ resonance approximately 0.3

Table 1 Key NMR data for complexes 1 - 3 .

\begin{tabular}{|c|c|c|c|}
\hline $\begin{array}{c}\text { Species, } \\
\text { Temperature }\end{array}$ & $(\delta),{ }^{2} J_{\mathrm{PH}},{ }^{1} J_{\mathrm{HH}}(\mathrm{Hz})$ & ${ }^{31} \mathrm{P}$ & ${ }^{15} \mathrm{~N}$ \\
\hline 1, $325 \mathrm{~K}$ & $\begin{array}{l}-21.03(\mathrm{td}), 17.2,-7.2 \\
-21.82(\mathrm{td}), 16.3,-7.2\end{array}$ & 21.75 & -131 \\
\hline 2, $325 \mathrm{~K}$ & $\begin{array}{l}-19.22(\mathrm{td}), 17.1,-7.1 \\
-22.19(\mathrm{td}), 16.0,-7.1\end{array}$ & 20.65 & -137 \\
\hline 3a, $325 \mathrm{~K}$ & $\begin{array}{l}-21.37(\mathrm{td}), 16.0,-7.0 \\
-22.66(\mathrm{td}), 15.8,-7.0\end{array}$ & 23.11 & -177 \\
\hline $3 \mathbf{b}, 325 \mathrm{~K}$ & $\begin{array}{l}-21.00(\mathrm{td}), 16.9,-7.3 \\
-21.80(\mathrm{td}), 16.3,-7.3\end{array}$ & 21.81 & \\
\hline 3c, $325 \mathrm{~K}$ & $\begin{array}{l}-19.72(\mathrm{td}), 17.1,-7.1 \\
-21.86(\mathrm{td}), 15.6,-7.1\end{array}$ & 21.95 & \\
\hline 3d, $325 \mathrm{~K}$ & $\begin{array}{c}-19.43(\mathrm{td}), 17.3,-7.3 \\
-21.60 *\end{array}$ & 22.61 & \\
\hline 4a, $325 \mathrm{~K}$ & $\begin{array}{l}-21.55(\mathrm{td}), 16.4,-7.2 \\
-22.78(\mathrm{td}), 16.0,-7.2\end{array}$ & 22.39 & -105 \\
\hline $\mathbf{4 b}, 325 \mathrm{~K}$ & $\begin{array}{l}-21.01(\mathrm{td}), 16.9,-7.1 \\
-21.83(\mathrm{td}), 16.1,-7.1\end{array}$ & 21.79 & \\
\hline 4c, $325 \mathrm{~K}$ & $\begin{array}{l}-20.69(\mathrm{td}), 16.4,-7.3 \\
-22.22(\mathrm{td}), 15.9,-7.3\end{array}$ & 19.91 & \\
\hline
\end{tabular}

determined.

ppm upfield from its free ligand value. The relatively small magnitude of the hydride signals of $\mathbf{3 b}$ are consistent with this assignment as the $\mathrm{N}^{3}$ position is generally considered the least basic, and is sterically hindered by the proximity of the fivemembered imidazole moiety. For 3c, the $\delta-21.86$ hydride signal exhibits one nOe connection to a ligated purine resonance at $\delta 8.45$. Since the $\mathrm{H}^{8}$ proton usually resonates at approximately $\delta 8.7$, it is evident that this signal has also been shifted approximately $0.3 \mathrm{ppm}$ upfield upon coordination. However, the assignment of this signal to the $\mathrm{H}^{8}$ proton does not distinguish between the $\mathrm{N}^{7}$-ligated product and the $\mathrm{N}^{9}$ ligated product, since both would be expected to show an nOe 
to $\mathrm{H}^{8}$. In this case, the absence of another nOe interaction in the spectrum due to $\mathrm{H}^{6}$ allows $3 \mathrm{c}$ to be assigned as containing an $\mathrm{N}^{9}$-ligated purine ligand. By comparison with 2 , which contains a benzimidazole ligand. The $\delta-22.19$ hydride signal of $\mathbf{2}$ does not show an nOe interaction to the proton between the two nitrogen atoms, analogous to purine- $\mathrm{H}^{8}$; however, it does exhibit a very strong nOe to a proton on the benzene ring moiety, analogous to purine- $\mathrm{H}^{6}$. In this way, the $\mathrm{N}^{7}$-ligated product would be expected to exhibit a much stronger nOe to the $\mathrm{H}^{6}$ proton than the $\mathrm{H}^{8}$ proton. This is not the case in the $\mathrm{N}^{9}$-ligated product, wherein $\mathrm{H}^{8}$ is the only proton in proximity. Unfortunately, the hydride signals of $\mathbf{3 d}$ are of insufficient magnitude to conduct NOESY experiments; however, the $\delta-19.43$ chemical shift of the trans-to-nitrogen hydride signal, along with the elimination of the other $\mathrm{N}$-donor sites, allows this species to be identified as the $\mathrm{N}^{7}$-coordinated isomer of $\operatorname{IrCl}(\mathrm{H})_{2}$ (purine) $\left(\mathrm{PPh}_{3}\right)_{2}$.

While the identification of the most abundant product $3 \mathbf{a}$ as containing a $\mathrm{N}^{1}$-ligated purine ligand is unsurprising, since the $\mathrm{N}^{1}$ site is the most basic and least sterically hindered, ${ }^{3}$ the temperature-dependent relative abundances of the other products is especially interesting. At $305 \mathrm{~K}, \mathbf{3 b}$ is present in greater quantities than 3c. At $325 \mathrm{~K}$, this position is reversed. This is a consequence of the temperature-dependent tautomerism of purine, in which the proportion of the $\mathrm{N}^{7}-\mathrm{H}$ tautomer increases upon heating.

The data from the purine system was then used as an aid when exploring the binding of adenine. An NMR tube was prepared as before, charged with $0.9 \mu \mathrm{mol}(0.7 \mathrm{mg})$ of $\mathrm{IrCl}(\mathrm{CO})\left(\mathrm{PPh}_{3}\right)_{2}$ and $3.7 \mu \mathrm{mol}(0.5 \mathrm{mg})$ of adenine, and examined at $325 \mathrm{~K}$. The high field region of the resultant ${ }^{1} \mathrm{H}$ NMR spectrum contained four new enhanced triplet of antiphase doublet resonances: one pair of hydride signals arising from $4 \mathbf{a}$, at $\delta-21.37$ and $\delta-22.74$, and another pair of hydride signals at $\delta-20.90$ and $\delta-21.75$, arising from $4 \mathbf{b}$. Both sets of signals are relatively weakly enhanced at this temperature, although those of $\mathbf{4 a}$ are significantly greater in magnitude than those of $\mathbf{4 b}$. Raising the temperature of the sample to $325 \mathrm{~K}$ had the effect of altering the chemical shifts of the hydride resonances of $\mathbf{4 a}$ and $\mathbf{4 b}$, while increasing the magnitudes of both sets of signals. New enhanced hydride resonances $(\delta-20.69$ and $\delta-22.22)$ are also observed, which are assigned to $\mathbf{4 c}$. At this temperature, the integral values of the resonances indicate that, while 4a still appears far greater in magnitude than the other isomers, $\mathbf{4} \mathbf{c}$ is present in greater quantity than $\mathbf{4 b}$. The products $\mathbf{4 a - c}$ were characterised by NMR methods at this temperature (Table 1), and assigned as three different isomers of $\operatorname{IrCl}(\mathrm{H})_{2}$ (adenine) $\left(\mathrm{PPh}_{3}\right)_{2}$.

The many similarities between the complexes 3a-c and $\mathbf{4 a - c}$ support the identification of the latter as complexes containing $\mathrm{N}^{1}-, \mathrm{N}^{3}-$ and $\mathrm{N}^{9}$-coordinated adenine ligands respectively. These assignments are supported by NOESY experiments, and the observation of the same temperature dependence in their formation as was observed with the purine-containing complexes. The most significant difference in behaviour of the two substrates is the absence of a $\mathrm{N}^{7}$-coordinated isomer of $\operatorname{IrCl}(\mathrm{H})_{2}$ (adenine) $\left(\mathrm{PPh}_{3}\right)_{2}$. This is caused by the $-\mathrm{NH}_{2}$ substituent of adenine: though it acts to increase the overall basicity of adenine in comparison with purine, it also sterically hinders metal binding at both the $\mathrm{N}^{7}$ and $\mathrm{N}^{1}$ positions, which appears to retard $\mathrm{N}^{7}$-metal binding to such an extent that the $\mathrm{N}^{7}$-coordinated form of $\operatorname{IrCl}(\mathrm{H})_{2}$ (adenine) $\left(\mathrm{PPh}_{3}\right)_{2}$ is not observed.

\section{Notes and references}

1 A. Broo and A. Holmén, Chemical Physics, 1996, 211, 147

2 SDBSWeb: http://www.aist.go.jp/ROIDB/SDBS/ (30/06/2004).

3 See for example, Metal Ions in Biological Systems, Vol. 32, 61- 89, R. B. Martin. A. Sigel and H Sigel Editors, Marcel Dekker Inc. New York, 1996 